TARNOWSKIE STUDIA TEOLOGICZNE 37 (2018) NR 1-2, S. 97-110 http://dx.doi.org/10.15633/tst.3253

ks. Jacek Soprych ${ }^{1}$

UNIWERSYTET PAPIESKI JANA PAWŁA II W KRAKOWIE

\title{
Obecność cudownego wizerunku Matki Bożej Laskawej ze Lwowa w Tarnowie i wątki tarnowskie w biografii abp. Eugeniusza Baziaka
}

Obecność cudownego wizerunku Matki Bożej Łaskawej ze Lwowa w Tarnowie związana jest bezpośrednio z osobą Biskupa Wygnańca Eugeniusza Baziaka $(1890-1962)^{2}$. Przyszły arcybiskup urodził się 8 marca 1890 roku w Tarnopolu.

${ }^{1}$ Ks. Jacek Soprych - asystent w Katedrze Patrologii i historii Kościoła na Wydziale Teologicznym Sekcja w Tarnowie Uniwersytetu Papieskiego Jana Pawła II w Krakowie, wykładowca historii Kościoła.

2 Eugeniusz Baziak - urodził się 8 marca 1890 roku w Tarnopolu. Po ukończeniu w 1908 roku gimnazjum wstąpił do Wyższego Seminarium Duchownego we Lwowie. W 1912 roku przyjął święcenia kapłańskie. Był katechetą w Żółkwi, kapelanem wojskowym, wikarym i katechetą w Tarnopolu. W 1919 roku został prefektem lwowskiego seminarium, a w 1924 roku jego wicerektorem. W 1931 roku objął probostwo w Stanisławowie, a dwa lata później został konsekrowany na biskupa. Po napaści sowieckiej na Polskę w 1939 roku zaangażował się w działalność dobroczynną, a po śmierci abp. Twardowskiego w 1944 roku, objął rządy jako metropolita lwowski. Czterokrotnie był przesłuchiwany przez władze sowieckie. Opuścił Lwów 27 kwietnia 1946 roku, eskortowany przez NKWD. W 1951 roku przybył do Krakowa, jako koadiutor kardynała Sapiehy. Po śmierci krakowskiego metropolity przejął kierowanie diecezją. Gdy odmówił potępienia księży aresztowanych pod zarzutem szpiegostwa, znalazł się w areszcie domowym. 16 grudnia 1952 roku sam został aresztowany pod zarzutem szpiegostwa. Po 8 dniach przesłuchań został wypuszczony z nakazem opuszczenia Krakowa. Zatrzymał się w Tarnowie, w domu matki i siostry. W 1956 roku powrócił do Krakowa; dwa lata później konsekrował 38-letniego ks. Karola Wojtyłę, którego uczynił sufraganem. „Pragnę mieć biskupa do roboty, a nie do ozdoby" - mówił wtedy, tłumacząc wybór młodego kapłana. Zmarł 15 czerwca 1962 roku po obradach Konferencji Episkopatu Polski w Warszawie. Został pochowany w wawelskiej katedrze, w krypcie pod kaplicą Zebrzydowskich. Zob. M. Rechowicz, Baziak Eugeniusz, w: Encyklopedia katolicka, t. 2, red. F. Gryglewicz, R. Łukaszyk, Z. Sułowski, Lublin 1985, k. 128; J. Jesionka, Arcybiskup Eugeniusz Baziak - konsekrator ks. Karola Wojtyły, „Niedziela”. Edycja bielsko-żywiecka 6 (2014), s. 4. 
Jego korzenie wywodzą się jednak z diecezji tarnowskiej - dziadek, Wojciech Baziak, pochodził z Łącka, gdzie z żoną Katarzyną z Mikołajczyków był właścicielem młyna wodnego i tartaku. Tu na świat przyszedł ojciec przyszłego biskupa Józef, który podjął studia na Uniwersytecie Wiedeńskim i został urzędnikiem sądowym w Tarnopolu³.

\section{Tarnów i diecezja tarnowska w życiorysie abp. Eugeniusza Baziaka}

Śledząc wątki tarnowskie w biografii Eugeniusza Baziaka, trzeba zatrzymać się przy jego sakrze biskupiej. Papież Pius XI 15 września 1933 roku ogłosił go biskupem tytularnym Phocea i sufraganem metropolity lwowskiego abp. Bolesława Twardowskiego. Konsekracja nowego biskupa odbyła się 5 listopada 1933 roku w archikatedrze lwowskiej. Konsekratorem był abp Bolesław Twardowski - metropolita lwowski, współkonsekratorami byli biskupi tarnowscy: ordynariusz bp Franciszek Lisowski i sufragan bp Edward Komar ${ }^{4}$. Z bp. Lisowskim znali się i przyjaźnili z wcześniejszej współpracy w lwowskim seminarium duchownym. Byli też nominowani przez abp. Bolesława Twardowskiego w 1928 roku na sufragana lwowskiego. Ojciec święty wybrał wówczas ks. Lisowskiego5. Już jako ordynariusz tarnowski bp Lisowski gościł go w swojej stolicy biskupiej w Tarnowie, m.in. na uroczystościach odpustowych w katedrze 9 września 1934 roku$^{6}$. Kilka lat później, 7 czerwca 1939 roku, bp Baziak oddał mu ostatnią ziemską przysługę i uczestniczył w jego pogrzebie ${ }^{7}$.

Kilka miesięcy po śmierci metropolity lwowskiego, 22 listopada 1944 roku, ojciec święty powierzył mu ten urząd ${ }^{8}$. Wojenne losy ojczyzny i Kościoła, martyrologium narodu polskiego i duchowieństwa stały się jego udziałem. Po II wojnie światowej, gdy nastąpiła zmiana granic państwowych, Lwów pozostał

3 W. Szetelnicki, Arcybiskup Wygnaniec Eugeniusz Baziak metropolita lwowski, Kraków 1989, s. 37 .

4 Archbishop Eugeniusz Baziak, http://www.catholic-hierarchy.org/bishop/bbazi.html (12.04.2018).

5 J. Soprych, Biskup Tarnowski Franciszek Lisowski (1876-1939). Teolog i duszpasterz, Tarnów 2017, s. 37, 54.

6 Z Tarnowa, „Nasza Sprawa” 1934 nr 37, s. 11.

7 Gdy odszedł od nas!, „Wiadomości Parafii Katedralnej” 1939 nr 24, s. 3.

8 M. Leszczyński, Archidiecezja Lwowska obrząku łacińskiego w granicach Polski 19441992, Lublin 2011, s. 44. 
poza Polską. Polacy znaleźli się w niezwykle trudnej sytuacji. Nie chcieli dobrowolnie opuszczać swojej ojcowizny. Nie mieli jednak wyjścia. Następowały liczne aresztowania i wywózki. Aresztowano wiele osób związanych z polską administracją, sądownictwem, życiem gospodarczym. Zamknięto większość polskich szkół, a uniwersytet szybko ukrainizowano. Władze stalinowskie traktowały Polaków jako wrogów systemu radzieckiego. Decyzję o wyjeździe przyspieszały także napady nacjonalistów ukraińskich na wsie i miasteczka. Zagrożenie życia i utraty dobytku sprawiało, że Polacy masowo opuszczali swoje domy ${ }^{9}$. Doświadczył tego także abp Baziak. Nie tylko wiadomości o okrucieństwach popełnianych na diecezjanach, ale też naciski i przymus władz sowieckich spowodowały, że 20 sierpnia 1945 roku zmuszony został wyprowadzić się z rezydencji arcybiskupiej przy ul. Czarnieckiego 32. Zamieszkał w klasztorze franciszkanów przy ul. Franciszkańskiej 1, gdzie mieszkał przed laty o. Maksymilian Kolbe ${ }^{10}$. Nie mógł jednak zatrzymać się u nich na dłużej. W Niedzielę Wielkanocną, 21 kwietnia 1946 roku, odprawił w katedrze lwowskiej ostatnią mszę pontyfikalnąa ${ }^{11}$ Kilka dni później, 26 kwietnia 1946 roku, eskortowany przez NKWD opuścił Lwów w pierwszym transporcie ${ }^{12}$. Już nigdy nie powrócił do swej stolicy biskupiej.

W drodze do Lubaczowa - największego miasta skrawka archidiecezji lwowskiej w nowych granicach Polski, gdzie przygotowano mu mieszkanie - arcybiskup zatrzymał się w Przemyślu u ks. bp. Franciszka Bardy, a następnie u sióstr józefitek. 6 maja przyjechał do Tarnowa i również zamieszkał w klasztorze sióstr józefitek. W ciągu kilku dni spotkał się z biskupem nominatem Janem Stepąa $a^{13}$, pracownikami kurii diecezjalnej, duchowieństwem diecezjalnym i zakonnym. Z odwiedzinami udał się do swej matki Franciszki, która mieszkała wówczas

9 W. Szetelnicki, Arcybiskup Wygnaniec..., s. 83.

${ }^{10}$ W. Szetelnicki, Arcybiskup Wygnaniec..., s. 10o; zob. Jan Paweł II, Wstańcie, chodźmy!, Kraków 2004, s. 15.

${ }^{11}$ J. T. Petrus, Lwowska katedra obrządku łacińskiego pw. Wniebowzięcia Najświętszej Maryi Panny. Przewodnik, Warszawa 1999, s. 30.

${ }_{12}$ J. Waligóra, Cierpiący Pasterz. Ks. arcybiskup - metropolita lwowski Eugeniusz Baziak (1890-1962), Rzeszów 2013, s. 123-137.

${ }^{13}$ Jan Stepa ur. 24 czerwca 1892 roku w Sasowie, zm. 29 maja 1959 roku Tarnowie. Był rektorem lwowskiego seminarium duchownego, które po zmianie granic przeniesione zostało do klasztoru Bernardynów w Kalwarii Zebrzydowskiej. Był też wikariuszem generalnym abp. E. Baziaka. Pius XII mianował go biskupem tarnowskim 4 marca 1946 roku. Sakrę przyjął 19 maja 1946 roku. Zob. A. Nowak, Słownik biograficzny kapłanów Diecezji Tarnowskiej 1786-1985 [dalej: sвкDT], t. 1, Tarnów 1999, s. 52-53. 
w Porębie Spytkowskiej ${ }^{14}$. Głównym powodem przyjazdu była konsekracja biskupia jego przyjaciela ks. Stepy, nowego ordynariusza diecezji tarnowskiej. Konsekratorem był metropolita krakowski kard. Adam Stefan Sapieha, a współkonsekratorami abp Eugeniusz Baziak i bp Stanisław Rospond ${ }^{15}$. Od nowego biskupa tarnowskiego otrzymał mieszkanie przy ul. Limanowskiego 15/3, gdzie przeniosła się jego mama $\mathrm{z}$ siostrą ${ }^{16}$.

W Lubaczowie zamieszkał dopiero 13 sierpnia 1946 roku w przygotowanym dla niego domu ${ }^{17}$. Nie zagościł tam zbyt długo. Decyzją papieża Piusa XII w 1951 roku przybył do Krakowa jako koadiutor kard. Sapiehy. Po jego śmierci przejął kierowanie diecezją. Był to okres nasilonej walki z religią, zastraszania i terroru. Represje były przemyślane, uciążliwe, długofalowe i zmierzały zarówno do materialnego, jak i moralnego zniszczenia Kościoła. Funkcjonariusze Urzędu Bezpieczeństwa stworzyli wśród duchownych sieć agenturalną, dzięki której gromadzili nie tylko informacje o duchowieństwie, planach duszpasterskich i działalności Kościoła, ale także starali się na niego wpływać ${ }^{18}$. Szczególną wagę przykładano do uderzania w hierarchię kościelną. Na porządku dziennym było fingowanie procesów, ferowanie surowych wyroków czy formułowanie oskarżeń sugerujących zdradę stanu. Jednym $\mathrm{z}$ elementów tej walki był pokazowy proces księży z kurii krakowskiej. Gdy abp Baziak odmówił potępienia księży aresztowanych pod zarzutem szpiegostwa, sam znalazł się w areszcie domowym. 16 grudnia 1952 roku trafił do więzienia przy ul. Montelupich. Ciągłe przesłuchania spowodowały gwałtowne pogorszenie się stanu jego zdrowia. Po 8 dniach został przez władze bezpieczeństwa przewieziony do Krynicy celem odbycia dłuższej kuracji. W wyniku decyzji władz państwowych PRL-u arcybiskup nie mógł powrócić do Krakowa i nie wolno mu było przebywać na terenie archidiecezji krakowskiej $^{19}$. Nie mógł też rezydować w Lubaczowie, więc po przeprowadzonej kuracji udał się do Tarnowa.

${ }^{14}$ M. Leszczyński, Archidiecezja Lwowska..., s. 28.

15 B. Kumor, Diecezja Tarnowska. Dzieje ustroju i organizacji 1786-1985, Kraków 1985, s. 294; Bishop Jan Piotr Stepa, http://www.catholic-hierarchy.org/bishop/bstepa.html (12.04.2018).

${ }^{16}$ Dokładny adres zamieszkania znajdziemy m.in. w Liber mortuorum parafii katedralnej.

${ }^{17}$ W. Szetelnicki, Arcybiskup Wygnaniec..., s. 102.

${ }_{18}$ Nigdy przeciw Bogu. Komunistyczna bezpieka wobec biskupów polskich, red. J. Marecki, F. Musiał, Warszawa-Kraków 2007, s. 9.

${ }_{19}$ M. Leszczyński, Archidiecezja Lwowska..., s. 46-48. 
Zamieszkał u swej matki Franciszki i siostry Marii ${ }^{20}$. Druga siostra Władysława ${ }^{21}$, która była nauczycielką, mieszkała na plebanii w Porębie Spytkowskiej i prawie przez 25 lat uczyła w miejscowej szkole ${ }^{22}$. Później przeniosła się do Tarnowa. Opiekę nad arcybiskupem roztoczyły siostry zakonne z dwóch zgromadzeń: józefitek i służebniczek dębickich. W mieszkaniu przy ul. Limanowskiego zamieszkała, wraz z arcybiskupem i jego rodziną, s. Julitta Dominik - służebniczka. Jej szczególnym zadaniem była opieka nad chorą matką arcybiskupa. Ze względu na stały kontakt $\mathrm{z}$ internowanym hierarchą s. Julitta była pod ścisłą obserwacją agentury. Opracowywano wobec niej plany werbunku, gdyż nie posiadano dostępu do "głównego figuranta” - abp. Baziaka ${ }^{23}$. Także tarnowskie siostry józefitki $\mathrm{z}$ wielkim zaangażowaniem pomagały arcybiskupowi. Szczególnie s. Illuminata Michalska i ówczesna przełożona generalna s. Eugenia Rekucka. Pierwsza jako zakrystianka posługiwała też w domowej kaplicy, na którą arcybiskup zaadaptował część mieszkania ${ }^{24}$. W swoich wspomnieniach mówiła o tym s. Julitta: „W pokoju na komodzie urządziłam ołtarzyk, na nim była odprawiana Msza Święta codziennie, potem wszystko chowałam"25. W czasie jego internowania w Tarnowie, 29 marca 1954 roku, zmarła matka. Pochowano ją w grobowcu sióstr józefitek na Starym

${ }^{20}$ Maria z Baziaków Szikulowa ur. 15 maja 1891 roku w Tarnopolu, zm. 23 października 1970 roku w Tarnowie, spoczywa w nowym grobowcu sióstr józefitek na Starym Cmentarzu w Tarnowie. Zob. Archiwum Parafii Katedralnej w Tarnowie [dalej APK], Liber mortuorum 1970, rkps, bez sygn., s. 46, nr 208.

${ }^{21}$ Władysława Baziak, panna, ur. 12 marca 1893 roku w Tarnopolu, zm. 16 kwietnia 1970 roku w Tarnowie, spoczywa w nowym grobowcu sióstr józefitek na Starym Cmentarzu w Tarnowie. W grobowcu tym spoczywa także trzecia siostra - Helena z Baziaków Kotowicz, zm. 26 kwietnia 1979 roku. Zob. APK, Liber mortuorum 1970, rkps, bez sygn., s. 27, nr 79; zob. Tablica na nowym grobowcu sióstr józefitek na Starym Cmentarzu w Tarnowie.

${ }^{22}$ J. Pytka, Poręba Spytkowska. Z dziejów wioski i parafi, Poręba Spytkowska 2017, s. 205206.

${ }^{23}$ Służebniczki dębickie były związane $\mathrm{z}$ arcybiskupem od lat trzydziestych $\mathrm{xx}$ wieku, gdy posługiwał najpierw jako proboszcz w Stanisławowie, a następnie jako pasterz we Lwowie. Po wojnie siostry, uciekając przed reżimem sowieckim z Lwowa, wróciły do Polski z arcybiskupem, który „dla nich był jak ojciec, a nawet brat” (A. Skrzypek, Służebniczki Dębickie w diecezji tarnowskiej w latach 1891-1989, Dębica 2016, s. 370).

${ }^{24}$ S. Jaworska, Okruchy wspomnień o więzi Zgromadzenia Sióstr Św. Józefa z JE. Arcybiskupem Eugeniuszem Baziakiem, Tuchów 2016 (mps), s. 4.

${ }_{25}$ Zbiory własne s. Agnieszki Skrzypek, Relacja s. M. Julitty Janiny Dominik o czasach okupacji, o pracy Sióstr Służebniczek w Powroźniku, Tarnowie, Bochni i Krościenku w czasach PRL-u, spisana przez s. M. Agnieszkę Skrzypek w Krościenku 9 lipca 2011 r. 
Cmentarzu ${ }^{26}$. Biskup w niedługim czasie przeniósł się do klasztoru józefitek przy ul. Mościckiego 34, do przygotowanego mieszkania, w którym pozostał do końca internowania ${ }^{27}$.

\section{Zabezpieczenie lwowskich archiwaliów przywiezionych $z$ Lwowa}

Biskup Stepa darzył abp. Baziaka przyjaźnią i wielkim szacunkiem. Jeszcze jako rektor lwowskiego seminarium został wikariuszem generalnym metropolity Baziaka $^{28}$. Ksiądz Jan Rzepa w swoich wspomnieniach zwrócił uwagę na posługę świadczoną arcybiskupowi przez biskupa tarnowskiego. Jak zaznaczył, był świadkiem ich kontaktów i stale zaskakiwała go pomysłowość bp. Stepy, który zapraszał go na uroczystości, zabierał do różnych gości, m.in. do rezydującego w Tuchowie łódzkiego arcybiskupa seniora Włodzimierza Jasińskiego ${ }^{29}$. Łączyła ich nie tylko przyjaźń, ale i troska o Kościół lwowski. Udział w uroczystościach pogrzebowych bp. Stepy, 1 czerwca1959 roku, i przewodniczenie ceremonii stały się okazją do wynagrodzenia za jego dobroć ${ }^{30}$.

Biskup Stepa zabezpieczył archiwalia i wiele cennych przedmiotów kościelnych przywiezionych w ramach repatriacji ze Lwowa. Dowodem są inwentarze, których tytuły do dziś budzą zainteresowanie: Spis obrazów archidiecezji lwowskiej zdeponowanych w Muzeum Diecezjalnym w Tarnowie (31) z 22 X 1954 r. czy Inwentarz szat i naczyń liturgicznych ze Lwowa zdeponowanych w Katedrze Tarnowskiej z dnia 1 VIII $1957 r^{31}$. Takich miejsc, gdzie zdeponowano „lwowskie skarby", było na mapie Polski więcej. Arcybiskupowi zależało, by bezpiecznie wywieźć wszystko, co było możliwe ${ }^{32}$. Dotyczyło to zwłaszcza przedmiotów kultu, wyposażenia kościołów i kaplic: obrazów i rzeźb, naczyń i szat liturgicznych, bibliotek i archiwaliów. Przez dziesiątki lat nie ujawniano rzeczy wywiezionych. Często były osobno spakowane i przechowywane w miejscu, o którym wiedział

${ }^{26}$ Franciszka Baziak spoczywa w starym grobowcu sióstr józefitek na Starym Cmentarzu w Tarnowie.

${ }_{27}$ S. Jaworska, Okruchy wspomnień..., s. 4.

${ }^{28}$ B. Kumor, Diecezja Tarnowska..., s. 293.

${ }^{29}$ J. Rzepa, Zamyślenia przy sarkofagu biskupa Jana Stepy w 50 rocznicę jego śmierci, Tarnów 2008, s. 58-60, 167 .

${ }^{30}$ J. Waligóra, Cierpiący Pasterz..., s. 44-45.

${ }^{31}$ M. Leszczyński, Archidiecezja Lwowska..., s. 100.

${ }^{32}$ J. Waligóra, Cierpiący Pasterz..., s. 124. 
tylko ksiądz, który je przewiózł. Następne pokolenia proboszczów często nie wiedziały o pochodzeniu i włączały do dziedzictwa danego kościoła ${ }^{33}$.

Część lwowskich archiwaliów złożono w podziemiach kościoła Najświętszego Serca Pana Jezusa w Tarnowie. Przechowywano je tam przez 30 lat $^{34}$. Do dziś we wspomnianym kościele, w kaplicy Najświętszego Sakramentu znajduje się słynąca łaskami figura Chrystusa Frasobliwego z Lwowskiej Bazyliki Archikatedralnej. Odbiera ona cześć od 1945 roku. Ważnym miejscem zdeponowania cennych przedmiotów ze Lwowa była tarnowska katedra. Wśród skarbów katedry lwowskiej znalazła się srebrna trumienka z relikwiami bł. Jakuba Strzemię, który przed wiekami, w 1392 roku, w tym tarnowskim kościele przyjął sakrę biskupią ${ }^{35}$. Relikwiarz przechowywany był od 1946 aż do roku 1966, kiedy wikariusz kapitulny ks. Jan Nowicki sprowadził go do Lubaczowa ${ }^{36}$. Ponownie wrócił do Tarnowa w lipcu 1986 roku, zdeponowany na przechowanie do muzeum diecezjalnego ${ }^{37}$. Do skarbca krakowskiej katedry na Wawelu relikwiarz trafił w 1996 roku, kiedy złożył go tam w depozycie dzisiejszy kardynał Marian Jaworski jako pierwszy biskup diecezji lwowskiej po odnowieniu jej przez Jana Pawła $\mathrm{II}^{38} .5$ grudnia 2009 roku relikwie wróciły do Lwowa i umieszczone zostały w głównym ołtarzu rzymskokatolickiej katedry Wniebowzięcia Najświętszej Maryi Panny ${ }^{39}$.

\section{Obraz Matki Bożej Łaskawej}

Wśród lwowskich skarbów przechowywanych w Tarnowie najcenniejszym był wizerunek Matki Bożej Łaskawej, Ślicznej Gwiazdy Miasta Lwowa. Namalował go w 1598 roku Józef Szolc-Wolfowicz. To przed tym obrazem, pół wieku później, w dniu 1 kwietnia 1656 roku król Jan Kazimierz ślubował bronić wiary katolickiej i praw ludu, a Maryję obrał Królową Korony Polskiej. Arcybiskup Baziak po drugiej wojnie światowej wywiózł dzieło do Polski. Nie mógł zostawić tak

3 Ks. Piotr Gajda, Relacja ustna, Tarnów, 20.04.2018.

${ }^{34}$ M. Leszczyński, Archidiecezja Lwowska..., s. 96.

35 A. Nowak, sBкDT, t. 1, s. 52-53.

${ }^{36}$ Relikwiarz ten wyeksponowany był na ołtarzu św. Kazimierza Królewicza.

${ }_{37}$ M. Leszczyński, Archidiecezja Lwowska..., s. 63, 177-178.

${ }^{38}$ M. Bartosik, Biskupi spór o skarby Lwowa, http://www.gazetakrakowska.pl/arty$\mathrm{kul} / 595123$,biskupi-spor-o-skarby-lwowa,id,t.html (5.06.2018).

${ }^{39}$ Błogosławiony Jakub Strzemie, http://www.rkc.lviv.ua/category_2.php?cat_1=8\&cat_2=84\&lang=3 (5.06.2018). 
wielkiego skarbu i narażać na profanację czy zniszczenie. Wszystko działo się $\mathrm{w}$ atmosferze strachu i tajemnicy. Czasowo w katedrze lwowskiej umieszczono pośpiesznie wykonaną przez Marię Pokiziak kopię, z dodatkowo nałożoną srebrną sukienką ${ }^{40}$.

Obraz Lwowskiej Madonny przechowywany był w różnych miejscach. Po tym jak wraz z abp. Baziakiem 26 kwietnia 1946 roku opuścił Lwów, trafił do skarbca na Wawelu, a następnie do skarbca w katedrze w Tarnowie. Pozostał tam aż do 1968 roku, kiedy to bp Jerzy Ablewicz przekazał go administratorowi apostolskiemu w Lubaczowie bp. Janowi Nowickiemu. Nie wiemy, czy obraz trafił do Tarnowa wraz z internowanym w 1953 roku arcybiskupem, czy może już wcześniej, np. w maju 1946 roku, kiedy arcybiskup przybył na sakrę bp. Stepy.

Powojenne losy obrazu Matki Boskiej Łaskawej omawiali prałaci i kanonicy gremialni Lwowskiej Kapituły Metropolitalnej w Lubaczowie na spotkaniu wraz z abp. Baziakiem 18 grudnia 1947 roku ${ }^{41}$. Jedno było pewne - obraz $\mathrm{w}$ Tarnowie był bezpieczny. Po powrocie $\mathrm{z}$ internowania arcybiskup pozostawił go pod opieką proboszcza katedry.

Po śmierci abp. Baziaka w 1962 roku kolejnymi administratorami apostolskimi archidiecezji w Lubaczowie byli biskupi: Jan Nowicki i Marian Rechowicz. Biskup Nowicki przejął obraz z Tarnowa i umieścił go w swojej prywatnej kaplicy w domu biskupim w Lubaczowie ${ }^{42}$. Pewne jest, że 2 lutego ${ }^{43} 1974$ roku biskup nominat Marian Rechowicz wprowadził uroczyście obraz do prokatedry w Lubaczowie ${ }^{44} .4$ maja 1980 roku Kapituła Metropolitalna, na wniosek bp. Rechowicza podjęła uchwałę o rekoronacji obrazu. W związku z tym zniszczone dzieło oddano do konserwacji w Krakowie. W latach 1981-1982 konserwował je prof. Józef Nykiel z Akademii Sztuk Pięknych w Krakowie. Zdjął wadliwą impregnację, przemalówki, uzupełnił ubytki, przywrócił pierwotną wartość artystyczną obrazu. On też wykonał dwie jego kopie, które

${ }^{40}$ M. Bartosik, Biskupi spór o skarby Lwowa, http://www.gazetakrakowska.pl/artykul/595123,biskupi-spor-o-skarby-lwowa,id,t.html (5.06.2018).

${ }^{41}$ J. Waligóra, Cierpiacy Pasterz..., s. 33.

${ }^{42}$ Konkatedra Lubaczów Sanktuarium NMP Łaskawej Lwowskiej, http://wp.kuboit.pl/matka-boza-laskawa-lwowska/(21.04.2018).

${ }^{43}$ Choć niektórzy będą podawać datę 3 marca. Zob. A. Łazar, Historia obrazu Matki Bożej Łaskawej. Śliczna Gwiazda miasta Lwowa - Maryja (II), http://niedziela.pl/artykul/46440/nd/ Sliczna-Gwiazda-miasta-Lwowa---Maryja-II (12.05.2018).

${ }^{44}$ M. Leszczyński, Archidiecezja Lwowska..., s. 156; A. Stopyra, Sanktuarium Najświętszej Maryi Panny Łaskawej Lwowskiej i Konkatedra w Lubaczowie, Lubaczów 2013, s. 11. 
przekazano do archikatedry we Lwowie i prokatedry w Lubaczowie. Papież Jan Paweł II nadał temu wizerunkowi jeszcze inną wartość. Podczas swej drugiej pielgrzymki do ojczyzny, w niedzielę 19 czerwca 1983 roku na Jasnej Górze, na skronie Matki Bożej Łaskawej nałożył papieskie korony ${ }^{45}$. Powiedział wówczas: „Z najwyższym wzruszeniem ozdabiam papieskimi koronami ten wizerunek, który był świadkiem ślubów Jana Kazimierza w katedrze lwowskiej w 1656 roku, wizerunek, przed którym Bogarodzica została po raz pierwszy nazwana Królową Korony Polskiej, a naród nasz zobowiązał się do nowego i gorliwego poświęcenia się na służbę swej Najmiłosierniejszej Królowej" ${ }^{46}$. 20 czerwca 1983 roku ozdobiony koronami przeniesiony został do kaplicy kurii arcybiskupiej, a następnie w procesji do prokatedry, gdzie odbyło się jego uroczyste powitanie. Mszę świętą celebrował bp Rechowicz, który wygłosił okolicznościowe kazanie. Po pewnym czasie, w związku z prowadzoną rozbudową prokatedry, obraz przeniesiono do kaplicy domu biskupiego, a w 1986 roku wywieziono ponownie do Tarnowa ${ }^{47}$. Ta informacja o drugiej obecności obrazu w Tarnowie nie ma potwierdzenia w żadnym źródle. W prokatedrze w Lubaczowie umieszczono jego wierną kopię z koronami papieskimi, którą 8 grudnia 1989 roku uroczyście intronizował bp Marian Jaworski. Oryginał cudownego obrazu - jako „relikwię narodową”, po konserwacji w Krakowie w 1991 roku, złożono w skarbcu katedry wawelskiej ${ }^{48}$.

Istotną kwestią są też miejsca przechowywania wizerunku Matki Bożej Łaskawej w samym Tarnowie. Jak wspominał ks. Piotr Gajda, kapelan i sekretarz bp. Stepy, było to objęte tajemnicą ${ }^{49}$. $Z$ tego powodu trudno dziś szczegółowo odtworzyć dokładną historię wędrówki obrazu. W książce Kraków. To jest wielka rzecz autor Stanisław Dziedzic pisze: „W okresie internowania arcybiskupa Baziaka przez władze PRL w Tarnowie, poza terytorium obu archidiecezji, obraz Matki Bożej Łaskawej znalazł schronienie najpierw

45 A. Łazar, Historia obrazu Matki Bożej Łaskawej. Śliczna Gwiazda miasta Lwowa - Maryja (II), http://niedziela.pl/artykul/46440/nd/Sliczna-Gwiazda-miasta-Lwowa---Maryja-II (12.05.2018).

${ }^{46}$ Jan Paweł II, Przemówienie po Mszy świętej koncelebrowanej pod przewodnictwem kard. Macharskiego, z okazji koronacji przez Ojca Świętego cudownych obrazów, Częstochowa 19 VI 1983, w: Druga pielgrzymka Jana Pawła II do Polski, Poznań-Warszawa 1984, s. 78.

${ }^{47}$ Konkatedra Lubaczów Sanktuarium NMP Łaskawej Lwowskiej, http://wp.kuboit.pl/matka-boza-laskawa-lwowska/(21.04.2018).

${ }^{48}$ Konkatedra Lubaczów Sanktuarium NMP Łaskawej Lwowskiej, http://wp.kuboit.pl/matka-boza-laskawa-lwowska/(21.04.2018).

${ }^{49}$ Ks. Piotr Gajda, Relacja ustna, Tarnów, 20.04.2018. 
w mieszkaniu prywatnym siostry biskupa w Tarnowie przy ul. Limanowskiego, a następnie w tamtejszym klasztorze sióstr józefitek" ${ }^{50}$. Mieszkanie w kamienicy przy ul. Limanowskiego 15/3, w którym zamieszkał abp Baziak, znajdowało się na parterze. Jedno z pomieszczeń przystosowano do odprawiania mszy świętych ${ }^{51}$. Tam też na ścianie zawisł lwowski wizerunek. Nie ma dowodów, by obraz miał być przechowywany u sióstr józefitek. Miejscem pewnym jest katedra. Biskup Leszczyński w monografii o archidiecezji lwowskiej zapisał, iż w 1954 roku obraz znajdował się w skarbcu, ale dwa lata później znalazł swoje miejsce w bocznym ołtarzu ${ }^{52}$. Biskup Stanisław Salaterski jako proboszcz tarnowskiej katedry wspominał, że obraz znajdował się w skarbcu, nigdy zaś nie był wystawiony do publicznej czci. Oprócz tych dwóch najważniejszych skarbów lwowskich (obrazu Matki Bożej Łaskawej i relikwiarza bł. Jakuba Strzemię) zdeponowane były także naczynia liturgiczne i tabernakulum ${ }^{53}$.

\section{Ukryte życie biskupa wygnańca}

Metropolita lwowski podczas pobytu w Tarnowie nie angażował się duszpastersko $^{54}$. Nie ma jakiegokolwiek śladu w zbiorach Archiwum Diecezjalnego w Tarnowie ani w Archiwum Seminarium Duchownego. Kroniki zakonne sióstr józefitek z czasu internowania osobiście nakazał zniszczyć abp Baziak ${ }^{55}$. Pomimo zakazu i trudności wyjeżdżał potajemnie do Lubaczowa i do Krakowa. W Tarnowie w 1955 roku wyświęcił dwóch kapłanów dla „archidiecezji w Lubaczowie" ${ }^{56}$. Leżały mu na sercu sprawy archidiecezji lwowskiej i krakowskiej, której był administratorem apostolskim. Wyjeżdżał też na krótkie odpoczynki do domu józefitek w Radnej Górze ${ }^{57}$. Przez cały czas był śledzony przez funkcjonariuszy służby bezpieczeństwa $\mathrm{z}$ powodu wywierania

S. Dziedzic, Kraków. To jest wielka rzecz, Kraków 2012, s. 251.

${ }^{51}$ S. Jaworska, Okruchy wspomnień..., s. 4; ks. Piotr Gajda, Relacja ustna, Tarnów, 20.04.2018.

${ }^{52}$ M. Leszczyński, Archidiecezja Lwowska..., s. 156.

${ }^{53}$ Bp Stanisław Salaterski, Relacja ustna, Tarnów, 20.04.2018.

${ }^{54}$ P. Gajda, Arcybiskup Wygnaniec Eugeniusz Baziak - w 60 rocznicę internowania $w$ Tarnowie (mps, b.m.w. i b.r.w.), s. 6.

55 S. Fides Rozkosz, Relacja ustna, Tarnów, 27.04.2018; S. Redempta Martyka, Relacja ustna, Kraków, 17.04.2018.

${ }^{56}$ M. Leszczyński, Archidiecezja Lwowska..., s. 121.

57 S. Jaworska, Okruchy wspomnień..., s. 4. 
„złego wpływu” na miejscowych biskupów ${ }^{58}$. Odwiedzali go kapłani krakowscy i lwowscy. Szczególna więź łączyła go z prymasem kard. Stefanem Wyszyńskim, z którym często korespondował. Prymas wielokrotnie wstawiał się do władz państwowych w sprawie abp. Baziaka. Przedstawiał go jako najbardziej lojalnego, spokojnego i umiarkowanego człowieka w gronie Episkopatu ${ }^{59}$. Później sam został internowany. Znamienne jest, że kiedy prymas przebywał w Komańczy, opracowywał program Wielkiej Nowenny przed Millenium Chrztu Polski oraz tekst Jasnogórskich Ślubów Narodu, abp Baziak przesłał mu wówczas z Tarnowa obrazek Matki Bożej Łaskawej. W odpowiedzi ksiądz prymas zapisał: „Z całego serca dziękuję za tak miły dar w postaci obrazu Matki Bożej Łaskawej, z Lwowskiej Katedry, przy którym zrodziło się Królowanie Maryi w Polsce. [...] A w Roku Ślubów Narodu pamiętam o Dziedzicu tej Katedry, która miała możność usłyszeć pierwsze Słowa ufności i oddania Polski - Królowej Nieba. Niech Virgo Auxiliatrix ${ }^{60}$ wspiera Waszą Ekscelencję i pośredniczy w odbieraniu Łask obfitych" ${ }^{61}$.

W kwietniu 1956 roku internowany prymas polecił bp. Zygmuntowi Choromańskiemu poruszyć w rozmowach w Komisji Mieszanej Rządu i Episkopatu m.in. zrewidowanie spraw usuniętych $\mathrm{z}$ diecezji biskupów, w tym sprawę abp. Baziaka ${ }^{62}$. Dzień przed powrotem prymasa do Warszawy, 27 października 1956 roku, bp Michał Klepacz jako przewodniczący Konferencji Episkopatu i bp Choromański w liście do Władysława Gomułki przedstawili „do uregulowania” pośród innych kwestii również sprawę abp. Baziaka. 27 listopada bp Choromański poinformował abp. Baziaka, że w Komisji Mieszanej ustalono jego powrót do Krakowa ${ }^{63}$. Nastąpiło to 3 grudnia 1956 roku. Z końcem 1959 roku o wszystkich tych sprawach, podczas wizyty ad limina apostolorum, 7 grudnia, osobiście opowiadał ojcu świętemu Janowi XXIII ${ }^{64}$.

Do wątków tarnowskich w biografii abp. Baziaka należą konsekracje biskupie. 5 października 1958 roku w kościele Najświętszego Serca Pana Jezusa

\footnotetext{
${ }^{58}$ M. Leszczyński, Archidiecezja Lwowska..., s. 48.

59 Stefan Wyszyński. Pro memoria, t. 1: 1948-1952, red. P. Skibiński, Warszawa 2017, s. 437.

${ }^{60}$ Dziewica Wspomożycielka.

${ }^{61}$ Cyt. za: W. Szetelnicki, Arcybiskup Wygnaniec, s. 120-121.

${ }^{62}$ S. Wyszyński, Zapiski więzienne, Warszawa-Ząbki 2001, s. 231-232.

${ }^{63}$ J. Żurek, Lwowskie losy abp. Eugeniusza Baziaka, „Biuletyn IPN” 2004 nr 12, s. 41.

${ }^{64}$ J. Waligóra, Cierpiący Pasterz..., s. 46.
} 
w Tarnowie arcybiskup konsekrował ks. Michała Blecharczyka ${ }^{65}$, drugiego sufragana tarnowskiego. Współkonsekratorami byli: bp Franciszek Barda, ordynariusz z Przemyśla i biskup pomocniczy z Tarnowa Karol Pękala ${ }^{66}$.

Jednym z ostatnich uroczystych wystąpień księdza arcybiskupa była konsekracja ks. Jerzego Ablewicza ${ }^{67}$ na biskupa tarnowskiego. Odbyła się 20 maja 1962 roku w przemyskiej katedrze. Jako metropolita był głównym konsekratorem nowego biskupa. Współkonsekratorami byli: sufragan tarnowski bp Pękala oraz przemyski ordynariusz bp Barda ${ }^{68}$.

Arcybiskup wygnaniec zmarł nagle 15 czerwca 1962 roku po obradach Konferencji Episkopatu Polski w Warszawie, w przeddzień ogłoszenia jego nominacji na arcybiskupstwo krakowskie. Przyczyną śmierci był rozległy zawał serca. Przeprowadzający sekcję zwłok dr Marian Kusiak miał powiedzieć, że jego serce to była jedna wielka blizna, a zawałów musiało być nawet kilkanaście. Niektórzy wyliczają nawet 17 zabliźnionych ran w sercu ${ }^{69}$. Został pochowany w wawelskiej katedrze, w krypcie pod kaplicą Zebrzydowskich. Uroczystościom pogrzebowym przewodniczył Prymas Tysiąclecia ${ }^{70}$.

Pamięć o tym wielkim pasterzu na nowo powróciła do Tarnowa $\mathrm{z}$ okazji 65-lecia jego internowania w tym mieście i obecności oryginalnego wizerunku lwowskiej Matki Bożej Łaskawej. 5 maja 2018 roku wprowadzono jego kopię do dolnego kościoła św. Maksymiliana Kolbego, który stał się odtąd kaplicą Matki Bożej Łaskawej Królowej Korony Polskiej. Uroczystość ta była okazją, by przypomnieć te jakże ważne wydarzenia $\mathrm{z}$ historii naszej ojczyzny.

${ }^{65}$ Michał Blecharczyk ur. 26 sierpnia 1909 roku w Rabie Niżnej, zm. 10 września 1965 roku w Tarnowie. Święcenia kapłańskie otrzymał z rąk Leona Wałęgi 26 marca 1932 roku. Był ojcem duchownym i wykładowcą liturgiki w tarnowskim seminarium. 6 lipca 1958 roku Pius XI prekonizował go na biskupa tytularnego Jos i sufragana tarnowskiego. Zob. A. Nowak, sB KDT, t. 1, S. 22-24.

${ }^{66}$ B. Kumor, Diecezja Tarnowska ..., s. 360; A. Nowak, sB KDT, t. 1, s. 23.

${ }^{67}$ Jerzy Ablewicz ur. 1 listopada 1919 roku w Krośnie, zm. 31 marca 1990 roku w Tarnowie. Święcenia kapłańskie otrzymał 5 marca 1943 roku w Brzozowie z rąk bp. F. Bardy. 26 lutego 1962 roku papież Jan XXııı mianował go biskupem tarnowskim. Zob. A. Nowak, sBKDT, t. 1, s. 19-21.

${ }^{68}$ Zob. A. Nowak, sBкDT, t. 1, s. 19.

${ }^{69}$ P. Zuchniewicz, Habemus Papam, Warszawa 2009; Homilia bpa Andrzeja Jeża w czasie Mszy Krzyżma Świętego, Tarnów-Katedra, 29.03.2018, http://formacja.diecezja.tarnow. $\mathrm{pl} / 2018 /$ o3/homilia-bpa-andrzeja-jeza-w-czasie-mszy-krzyzma-swietego/(12.05.2018).

${ }^{70}$ M. Leszczyński, Archidiecezja Lwowska..., s. 53. 


\section{Bibliografia}

Gajda Piotr ks., Relacja ustna, Tarnów, 20.04.2018.

Jaworska S., Okruchy wspomnień o więzi Zgromadzenia Sióstr Św. Józefa z JE Arcybiskupem Eugeniuszem Baziakiem, Tuchów 2016 (mps).

Leszczyński M., Archidiecezja Lwowska obrządku łacińskiego w granicach Polski 1944-1992, Lublin 2011.

Martyka Redempta s., Relacja ustna, Kraków, 17.04.2018.

Petrus J. T., Lwowska katedra obrządku łacińskiego pw. Wniebowzięcia Najświętszej Maryi Panny. Przewodnik, Warszawa 1999.

Rozkosz Fides s., Relacja ustna, Tarnów, 27.04.2018.

Rzepa J., Zamyślenia przy sarkofagu biskupa Jana Stepy w 50 rocznicę jego śmierci, Tarnów 2008.

Salaterski Stanisław bp, Relacja ustna, Tarnów, 20.04.2018.

Skrzypek A., Stużebniczki Dębickie w diecezji tarnowskiej w latach 1891-1989, Dębica 2016.

Szetelnicki W., Arcybiskup Wygnaniec Eugeniusz Baziak metropolita lwowski, Kraków 1989.

Waligóra J., Cierpiący Pasterz. Ks. arcybiskup - metropolita lwowski Eugeniusz Baziak (1890-1962), Rzeszów 2013.

Zbiory własne s. Agnieszki Skrzypek, Relacja s. M. Julitty Janiny Dominik o czasach okupacji, o pracy Sióstr Służebniczek w Powroźniku, Tarnowie, Bochni i Krościenku w czasach PRL-u, spisana przez s. M. Agnieszkę Skrzypek w Krościenku 9 lipca $2011 \mathrm{r}$.

Żurek J., Lwowskie losy abp. Eugeniusza Baziaka, „Biuletyn IPN” 2004 nr 12, s. 41.

\section{Streszczenie}

Liczne związki abp. Eugeniusza Baziaka z Tarnowem, szczególnie jego zaufanie do pasterza diecezji bp. Jana Stepy, pozwoliły na złożenie w depozycie dwóch najcenniejszych skarbów metropolii lwowskiej - srebrnej trumienki z relikwiami bł. Jakuba Strzemię oraz obrazu Matki Bożej Łaskawej. Wizerunek Matki Bożej z lwowskiej katedry łacińskiej jest dla Polaków szczególną narodową pamiątką. To przed nim 1 kwietnia 1656 roku król Jan Kazimierz ślubował bronić wiary katolickiej i praw ludu, a Maryję obrał Królową Korony Polskiej. Po drugiej wojnie światowej zmieniły się granice naszej ojczyzny i Lwów pozostał poza nią. Arcybiskup 
Baziak wywiózł tę ważną relikwię do Polski. Nie mógł zostawić tak wielkiego skarbu. Nie mógł narażać go na profanację czy zniszczenie. Tarnów stał się ważnym przystankiem, gdzie przez wiele lat ukrywany był ten cenny wizerunek.

\section{Słowa kluczowe}

Eugeniusz Baziak, Jan Stepa, internowanie duchownych, Tarnów, Lwów, Matka Boża Łaskawa

\section{Summary}

\section{The Presence of the Miraculous Image of мв Grace from Lviv in Tarnow and the Tarnów themes in the Biography of the Archbishop Eugeniusz Baziak}

Numerous connections of Archbishop Eugeniusz Baziak with Tarnow, especially his trust to the pastor of the diocese Bishop Jana Stepa, allowed to place in the deposit two of the most valuable treasures of the metropolis of Lviv - a silver coffin with relics of Jakub Strzemię and the painting of Our Lady of Grace. The image of the Mother of God from the Lviv Latin Cathedral is a special national souvenir for Poles. It was in front of it on April $1^{\text {st }}, 1656$ that the King Jan Kazimierz vowed to safeguard the Catholic faith and the human rights and he chose the Blessed Virgin Mary as the Queen of the Polish Crown. After World War II borders of our homeland changed and Lviv remained outside. Archbishop Baziak took that important relic to Poland. He could not leave such a great treasure. He could not expose it to desecration or destruction. Tarnów has become an important stop, where for many years this precious image was hidden.

\section{Keywords}

Eugeniusz Baziak, Jan Stepa, internment of clergy, Tarnów, Lviv, Our Lady of Grace 